\title{
Untold Stories: Newark's Burgeoning West African Population and the In-School Experiences of African Immigrant Youth
}

\author{
Michael Simmons and Mahako Etta
}

\section{INTRODUCTION}

Notwithstanding the current political discourse, immigration to the United States is not a new phenomenon. More than 70 years ago, as he endeavored to write the history of immigration in the United States, Oscar Handlin (1951) astutely observed that immigrants are American history. Indeed, the history of the United States is the story of the movement of peoples from around the globe, each bringing with them a unique set of customs and beliefs. While each group of new arrivals to the shores of the United States has brought an extensive collection of talents and abilities,

\footnotetext{
M. Simmons

Joseph C. Cornwall Center for Metropolitan Studies, Rutgers University-

Newark, Newark, NJ, USA

e-mail: michael.simmons@rutgers.edu

M. Etta $(\bowtie)$

Rutgers University-Newark School of Public Affairs and Administration,

Newark, NJ, USA

e-mail: metta@scarletmail.rutgers.edu

(C) The Author(s) 2020

M. L. McLean (ed.), West African Youth Challenges and

Opportunity Pathways, Gender and Cultural Studies in Africa and the Diaspora, https://doi.org/10.1007/978-3-030-21092-2_4
} 
not all have arrived under the same set of circumstances, nor have their stories been equally represented in the retelling of the nation's migratory history. Arguably, in no case is this as true as it is for those arriving to the United States from the African continent.

There is a long history of African presence in the Americas. During the transatlantic slave trade in the sixteenth through nineteenth centuries alone, it is estimated that more than 12 million forced African migrants were transported to the United States (Segal, 1995). Early census data indicate that, as a result of forced migration, people of African descent accounted for close to one-fifth of the US population by the end of the eighteenth century (Anderson, 2015). Historical records indicate, and DNA testing has since confirmed, that many of those brought to the United States during the European slave trade originated from Western Africa. In fact, the presence of the Igbo peoples-a population from modern-day Nigeria - was so significant in parts of colonial Virginia that leading historian of slavery in North America Ira Berlin (1998) has referred to the region of the United States as "Igbo Land" to mark the African cultural influence that is still felt in the area today. Through the advent of genetic testing, today there are scores of African Americans, including celebrities ranging from Oprah Winfrey to Isaac Washington, who have traced their ancestry to West Africa (Halter \& Johnson, 2014).

Beyond the transatlantic slave trade, the mass movement of people of African descent continued to characterize the experiences of Black Americans well into the first half of the twentieth century. During the Great Migration-sometimes differentiated into three time frames from 1865 to 1896, again from 1910 to 1940 , and finally from 1940 to 1970 it is estimated that more than six million Blacks left the South for better opportunities in the northern and western regions of the United States (Mathieu, 2009). In total, the Great Migration represents one of the largest internal mass movements of individuals in US history (Lemann, 1991). Often missed in the analysis of the Great Migration is how similar the experiences of Black migrants were after their arrival to the northern and western parts of the United States to that of international immigrants coming to the United States. Like many international immigrants, Black migrants were confronted with linguistic and cultural adjustment challenges upon their arrival to their new designations. Additionally, the motivations for resettlement, including the "push" factors associated with the desire to leave behind the social and economic limitations of one environment and the aspirational "pull" factors associated with the promise of 
greater social and economic mobility, were another similarity shared by Black migrants and international immigrants. Interestingly, recent research by Alexander, Leibbrand, Massey, and Tolnay (2017), using census data from 1940 to 2000 , found that second-generation migrants leaving the South exhibited higher economic mobility and educational attainment than those who remained in the South and frequently outperformed their native counterparts.

\section{Changing Demographic Makeup of the US Immigrant Population}

Although African immigration to the United States in general, and to the state of New Jersey in particular, is a fairly recent development, commencing in earnest in the 1980s, the population's growth in the United States can be traced to national immigration policies enacted some 20 years earlier in the 1960s. Throughout much of Newark's early history, immigrations from Europe were the primary driver of population growth in Newark and other cities around New Jersey. In fact, the state's proximity to Ellis Island, the United States' most important early immigrant port of entry, placed New Jersey at the epicenter of the country's early European immigrant history. Quickly, New Jersey became a designation of choice for the new arrivals. In Newark alone, the city's Italian population grew from 400 in 1880 to over 25,000 by 1920 . Starting with the census of 1840 and continuing to the present, New Jersey has had one of the highest proportions of foreign-born populations (U.S. Census Bureau, 2014; Shaw, 1994).

At the turn of the twentieth century, immigrants made up more than a quarter of New Jersey's population. However, after World War I, economic uncertainties and rising xenophobic attitudes culminated in the passing of the National Origins Act of 1924. The act instituted national quotas and effectively limited immigration to the United States to individuals of Western and Northern European descent. In the 1960s, unprecedented economic growth and more inclusive social attitudes as a result of the Civil Rights Movement helped to set the stage for more progressive immigration policies. For instance, weeks after the passing of the Voting Rights Act of 1965, the Immigration and Nationality Act become the law of the land. Two of the more significant features of the act was the abolishment of the national origins preferential quota system that favored those 
of European descent and the creation of the family unification clause, enabling family members of permanent residents and naturalized citizens easier access to emigrate to the United States. Few individuals at the time understood the transformative impact the new immigration legislation would have on the demographic makeup of the country. Many assumed at the time of its enactment, as did the bill's cosponsor, Congressman Emanuel Celler, that

there will not be, comparatively, many Asians or Africans entering the country ... Since the people of Africa and Asia have very few relatives here, comparatively few could immigrate from those countries because they have no family ties to the U.S. (U.S. Congress, House of Representatives, 1965, pp. 21, 758)

While it would be decades before its full impact would be felt, the legislation helped to usher significant changes to the ethno-racial landscape of the United States. Due to the 1965 legislation, the percentage of immigrants admitted under the family unification provision increased from around $14 \%$ in the mid-1960s to 70\% by 1980 (Njue \& Retish, 2010). As reflected in Table 4.1, in 1970 the US foreign-born population represented less than $5 \%$ of the total population, its lowest level in the twentieth century. In each of the subsequent decades, the foreign-born population increased as a percent of the total US population from $6.2 \%$ in 1980 , to 13.5\% in 2016 (Grieco \& Trevelyan, 2010; Zong, Batalova, \& Hallock, 2018). Moreover, demographically the foreign-born population shifted from being comprised of those of European descent in the 1970s to being

Table 4.1 US foreign-born immigrant population

\begin{tabular}{lcc}
\hline Year & $\begin{array}{l}\text { Size of immigrant population } \\
\text { (millions) }\end{array}$ & $\begin{array}{l}\text { Immigrant share of total US population } \\
(\%)\end{array}$ \\
\hline 1970 & 9.6 & 4.7 \\
1980 & 14.1 & 6.2 \\
1990 & 19.8 & 7.9 \\
2000 & 31.1 & 11.1 \\
2010 & 40.0 & 12.9 \\
2016 & 43.7 & 13.5 \\
\hline
\end{tabular}

Source: Migration Policy Institute (MPI) (2017b) tabulation of data from the United States Census Bureau 2010 and 2016 American Community Surveys (ACS), and 1970-2000 decennial Census data 
made up of individuals immigrating from Latin American countries by 2016 (Grieco et al., 2012; Zong et al., 2018).

The increase in the foreign-born population was even more dramatic in New Jersey. The state's foreign-born population increased from $8.9 \%$ in 1970 to nearly $22 \%$ by 2016 (Matthau, 2017). Currently, there are approximately 1.9 million immigrants living in New Jersey, due in part to the growth of the non-European immigrant population in urban centers like Newark. Similar to national trends, Newark's foreign-born population is made up largely of new arrivals from South America. However, the fastest-growing population of Newark's foreign-born population are individuals emigrating from Africa, particularly from West African countries, which is also in line with national trends.

\section{Voluntary African Immigration to the United States}

Unlike the United States' extensive history of forced African migration, the voluntary resettlement of Africans ${ }^{1}$ to the United States is a relatively new development. Estimates suggest that between 1900 and 1950 only 31,000 Africans lived in the United States (Gordon, 1998). Even after the Immigration and Nationality Act in the 1960s, a first in a series of immigration reforms that would change the cultural landscape of the United States, African immigration continued to lag behind immigration patterns of individuals from other regions of the world. Despite sweeping changes to US immigration policies, previously established French and British colonial ties made Europe a more likely destination for Africans than the United States. Even in the case of Africans who did come to the United States, such as Kwame Nkrumah, the first prime minister of Ghana, or Nnamdi Azikiwe, the first president of Nigeria, the tendency was to come to the United States for educational opportunities and eventually return home. Consequently, in 1970 the foreign-born African population in the United States was only 80,000 , accounting for less than $1 \%$ of the nation's foreign-born population. However, African immigration has roughly doubled in each of the subsequent decades since 1970, with an increase by 29\% for sub-Saharan migration alone between 2010 and 2015 (Zong \& Batalova, 2017). Today, there are approximately 2.1 million foreign-born

\footnotetext{
${ }^{1}$ It should be acknowledged that depicting migration as voluntary can be problematic, given that migration that happens as a result of war, natural disaster, political persecution, or economic hardship could be considered a form of forced migration.
} 
Africans residing in the United States, representing close to 5\% of all US immigrants. The increase in the number of immigrants coming from the African continent, coupled with recent declines ${ }^{2}$ in Caribbean migration, has led demographers to conclude that by 2020 the number of Africans migrating to the United States will surpass those coming from the Caribbean (Capps, McCabe, \& Fix, 2011).

Today, new arrivals from the African continent represent the fastestgrowing population of immigrants to the United States (Anderson, 2017). Interestingly, the growth of African relocation to the United States has corresponded with a decline in African immigration to Europe. As immigration policies in the United States were becoming more open during the later half of the twentieth century, the opposite was taking place in Europe, where legislation sought to discourage migration from former African colonies. For instance, 1970s French legislation ended legal migration from the continent, while starting in the 1960s and continuing into the 1980s and 1990s, US legislation became more inclusive of African immigrants. The 1986 Immigration and Control Act, for example, expanded pathways for citizenship for undocumented immigrants, ultimately granting amnesty to over 30,000 Africans. Later, the 1990 Immigration Act created the Diversity Visa Program (commonly referred to as "the lottery") and broadened citizenship opportunities for those from underrepresented countries of origin (Halter \& Johnson, 2014). Notwithstanding the recent exponential growth of African immigrants, public policy attention and media commentary has continued to focus almost exclusively on immigrants from Mexico and Central America, the United States' largest immigrant community.

The rapid growth of African immigration to the United States over the past 50 years has not been without some distinct patterns regarding migrants' countries of origin and their final designation once they arrive in the United States. The West African region, particularly the countries of Nigeria and Ghana, has been the leading region of origin for African migrants coming to the United States. In total, 36\% of African immigrants have come from West Africa, followed by 29\% from East Africa and 17\% from North Africa. Within the United States, a quarter of all African immigrants have settled in the Northeast, drastically changing the

\footnotetext{
${ }^{2}$ It is not fully known why Caribbean migration has declined, although some, including sociologist Kevin Thomas (Thomas, 2011), have pointed to the recent economic recession in the United States as a contributing factor.
} 
immigrant population makeup of the region. In total, $27 \%$ of the foreignborn population of people of African descent in the United States reside in the New York-Newark-Jersey City metropolitan area, with foreign-born Blacks making up $28 \%$ of the total Black population in the region (Anderson, Lopez, \& Rohal, 2015). Nationally, the state of New Jersey has the fifth-largest African-born population, behind the more populous states of New York, California, and Texas, as well as the similarly sized state of Maryland (Gambino, Trevelyan, \& Fitzwater, 2014).

In New Jersey, where close to $20 \%$ of the state's residents are made up of those who are born outside of the country, the state's immigrant population is concentrated in urban centers (Grieco et al., 2012). In Newark alone, the city's 77,873 foreign-born residents represent more than $25 \%$ of the city's population and close to $4 \%$ of the state's foreign-born population. Moreover, New Jersey's African immigrant population has increased by $76 \%$ since 2000 , mainly due to new arrivals from North and West Africa (Anderson, 2015; U.S. Census Bureau, 2014). Following this trend, and as shown in Fig. 4.1, Newark's African immigrant population has increased by $76 \%$ since 2000 , primarily due to immigration from Ghana and Nigeria. In fact, the New York-Newark-Jersey City metropolitan area is the home of the largest population of African immigrants in the country, which provides a natural pathway for new immigrants to settle in the area through the family unification provisions first introduced in the Immigration and Nationality Act of 1965 (Edward, 2010; Halter \& Johnson, 2014).

Newark, New Jersey is made up of 5 political wards and 20 distinct neighborhoods. As reflected in Figs. 4.2 and 4.3, overall Newark's immigrant population is concentrated in the city's North and East Wards. This is particularly true for the city's burgeoning South American and Caribbean foreign-born communities. Conversely, the city's African immigrant population is concentrated in the city's South, Central, and West Wards. Within the city's wards, and displayed in Fig. 4.4, the largest percentage of immigrants with African ancestry reside in the Lower Clinton Hill neighborhood in the city's South Ward. African immigrants make up 8\% of the total population of Lower Clinton Hill, followed by $7.7 \%$ of the Springfield neighborhood in the Central Ward, and 7\% of the Westside neighborhoods in the West Ward (Statistical Atlas, 2018). 


\section{Recent Trends in Region and Country of Birth for Newark Immigrants}

Today, most immigrants living in Newark were born in South America. The number of South American immigrants continues to rise, growing by $26 \%$ from 2000 . However, immigrants from Central American and Africa have grown at exceptional rates. Immigrants from the Central American countries of Mexico and Honduras are growing faster than immigrants from any other country. Once prolific in Newark, numbers of European immigrants have plummeted since 2000

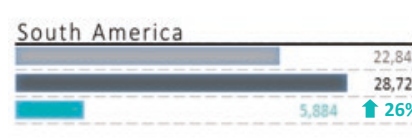

Caribbean

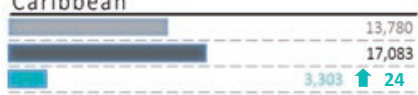

Central America

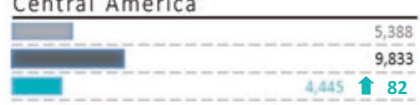

Europe
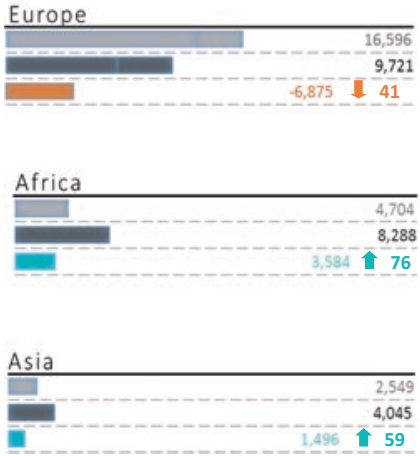
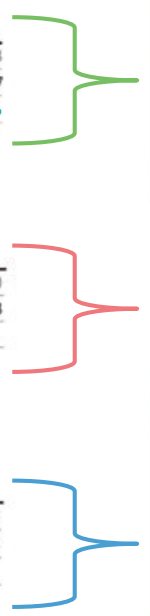

\begin{tabular}{|c|c|c|c|c|}
\hline & 2000 & $\begin{array}{l}2010- \\
2014\end{array}$ & $\begin{array}{l}\text { Number } \\
\text { Change }\end{array}$ & $\begin{array}{l}\text { Percent } \\
\text { Change }\end{array}$ \\
\hline Mexico & 1,290 & 3,290 & 2,000 & $+155 \%$ \\
\hline El Solvador & 1.695 & 2.462 & 767 & $.45 \%$ \\
\hline Honduras & 734 & 2,060 & 1,326 & $+181 \%$ \\
\hline Guatemala & 839 & 1,004 & 165 & $.20 \mathrm{~K}$ \\
\hline Remainder & 830 & 1.017 & 187 & $.23 \%$ \\
\hline
\end{tabular}
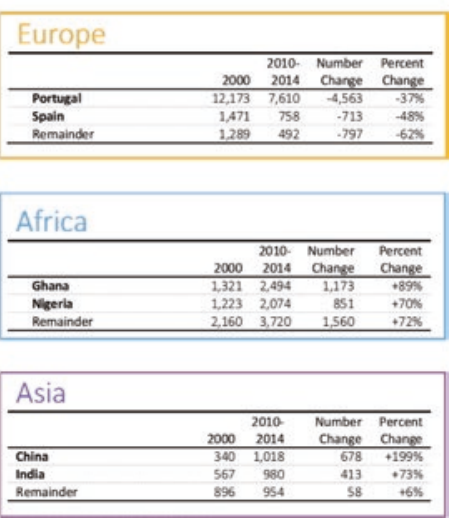

Cornwall Center Analysis of 2010 U.S. Decennial Census and 2010-2014 5-year A.C.S. data.

Fig. 4.1 Recent trends in region and country of birth for Newark immigrants 


\section{Immigration in Newark's Neighborhoods}

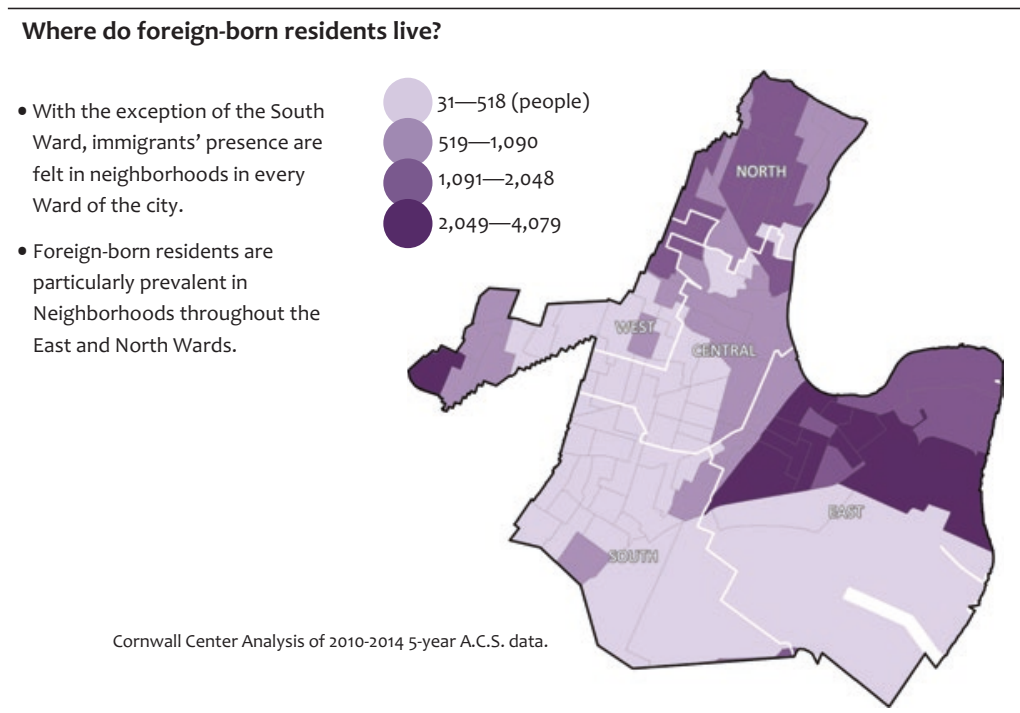

Fig. 4.2 Immigration in Newark's neighborhoods

\section{Understanding Newark's African Youth Immigrant EXPERIENCE}

Previous research on the African immigrant community in the Bronx, New York, may offer some insight into the population growth of the Newark community. In her oral history, sociologist Jane Edward (2010) noted that along with the opportunity to reunite with family members currently living in the United States, African immigrants in her study who perceived that the United States was a place of opportunity and a gateway to economic upward mobility made that a part of the decision to emigrate to the United States. Increasingly, as African immigrants invest in and take advantage of educational opportunities and find economic success, the emigration of additional relatives to the United States often involves younger family members. Consequently, a natural outcome from the growth of the immigrant community in the United States has been the corresponding rise in the immigrant youth population. Since the 1980s, the children of immigrants have become the fastest-growing segment of 


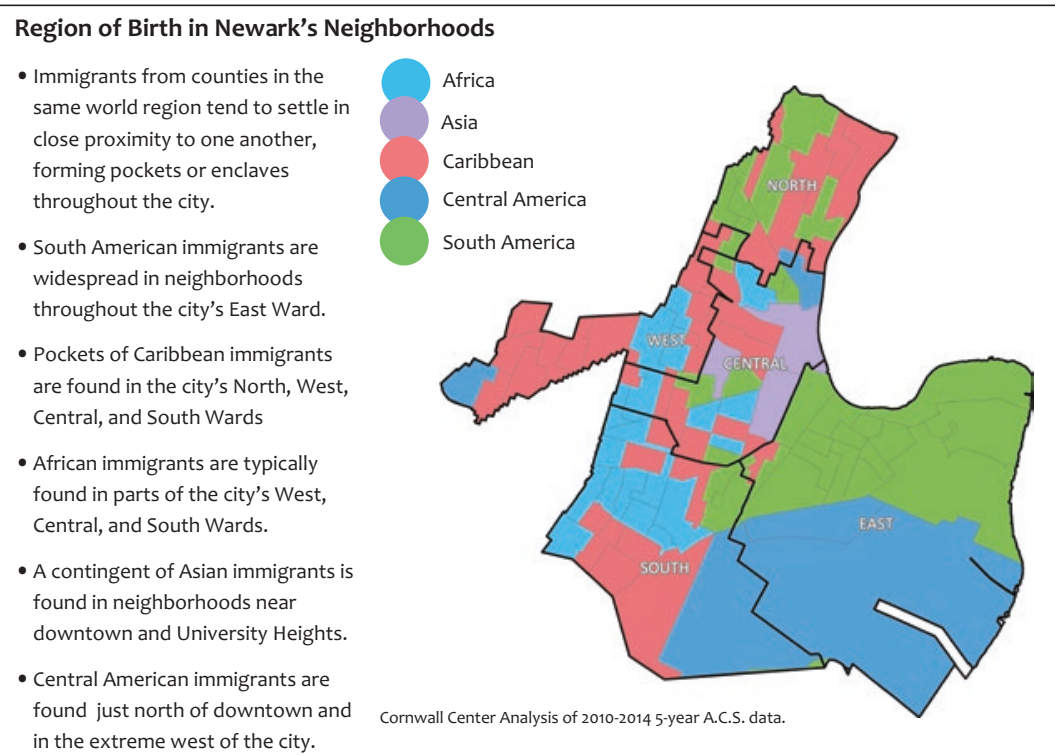

Fig. 4.3 Region of birth in Newark's neighborhoods

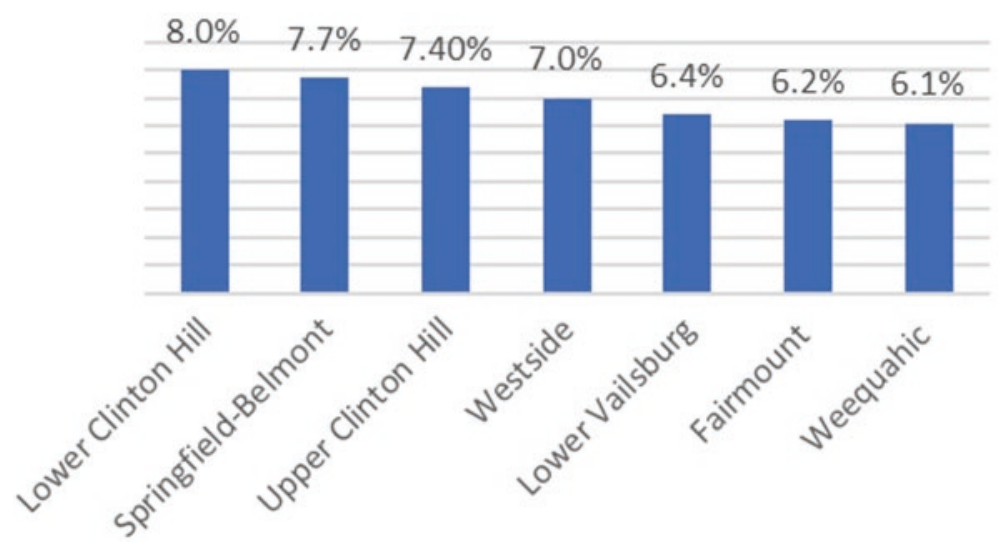

Fig. 4.4 Newark communities with the highest percentage of African immigrants: percentage of total population (Data from the United States Census Bureau accessed on the Statistical Atlas (2018) website in April of 2018) 
the youth population in the United States, accounting for close to onequarter of all children by 2015 . Today, there are more than 18 million immigrant children in the United States, with $62 \%$ of them clustered in California, New York, New Jersey, Florida, Illinois, and Texas. In total, $37 \%$ of children in New Jersey are born to immigrant parents (Migration Policy Institute, 2017a).

African immigrants are found in communities across New Jersey but remain concentrated in the state's urban centers. For communities like Newark, the large increase in African students can be particularly demanding on educational and community-based institutions-each of which are typically challenged by limited financial resources and social support systems. The challenges faced by immigrant young people can not only go unmet, but also remain hidden from the larger public. School officials with large populations of African students and nonprofit leaders within the African community, however, are often positioned to understand the challenges faced by educational and community-based systems that serve African youth.

\section{West African Students Within the Educational System}

An emerging narrative within scholarly research and popular literature posits that African immigrants are the new "model minority" in the United States. Within social science research, McCabe (2011) and Zong and Batalova (2017) reported that adult African immigrants are more likely to have college degrees than both other immigrants in the United States and people who are native born. Similarly, Anderson et al. (2015) and Gambino et al. (2014) showed that African immigrants have higher rates of advanced degrees than Asian immigrants or US-born citizens. In recent years, popular media has frequently highlighted the accomplishments of African students, such as Kwasi Enin, Priscilla Samey, and Ifeoma White-Thorpe, in ways that equally celebrate their scholastic achievements in being accepted into multiple Ivy Leagues colleges and that acknowledge their West African heritage.

Still others suggest that the experiences of young African immigrants are more nuanced than the model minority narrative would suggest. Ukpokodu (2018) called attention to the fact that many African immigrants reside in urban communities of color where "savage inequalities" continue to impact the academic achievement of students. Using a content analysis of scholarly literature of African immigrant students in K-12 
schools, Ukpokodu reported a lack of data to substantiate the model minority claim. Moreover, in their examination of African and African American student interactions in a public high school, Traoré and Lukens (2006) discovered that misperceptions about the continent permeated virtually all aspects of the educational setting in their study, which adversely impacted students' relationships with other students and their ability to bond with their teachers. The authors concluded that arguably the darkest thing about Africa is the United States' ignorance of it. The prevailing notion that Africa is backward and Africans are primitive, diseased, and uneducated at times created uneven teacher expectations about what African students are capable of achieving and undermined the ability of African and African American students to develop positive relationships.

To understand the challenges faced by Newark's African youth immigrant population, this research uses a case study profile of a West Ward Newark high school that has experienced a recent increase in West African immigrant students. As a research tool, case studies are particularly useful to gain a more granular understanding of a complex set of events. Often exploratory in nature and typically using a limited number of individuals as subjects, case studies allow the researcher to "investigate contemporary real-life phenomenon through detailed contextual analysis" (Zainal, 2007, p. 2). The case study includes a series of stakeholder interviews with school personnel (principal, teacher, director of student support services) and the director of a college preparation program who serves as a prominent community partner to the high school. Due to the recent influx of West African students, the local high school has implemented a series of proactive academic and social programming measures to address the needs of African students and their families.

The interviews revealed important insight into the opportunities and challenges faced by institutions attempting to serve West African youth. Within the educational context, school personnel reported that in recent years there has been an increase in the number of African immigrant students who are arriving to the United States for the first time as teenagers. With a student population of just over 1200 students, the high school principal estimated that in recent years the first-time enrollment of West African students aged 16 to 17 years has been close to 100 students annually-easily outpacing the enrollment rates of other immigrant youth. Like many school districts around the country, Newark Public Schools currently do not have a reporting system in place to disaggregate students beyond broad racial and ethnicity categories to trace Black students' coun- 
try of origin or recent African immigration status. For instance, district schools rely on information polling of their student populations. Informal surveying of the West African student population conducted by the school's student support services office suggests that the majority of the local high school's West African students have emigrated from Nigeria and that a substantial number of the students are Muslim. Furthermore, general data obtained from students suggest that greater access to social and economic upward mobility was the primary reason their families immigrated to the United States.

Because of the lack of student tracking data on students' recent African immigration status, school officials found that their immediate challenge was in recognizing that the demographics of their school was in fact changing. For school officials, this revelation happened during several end-of-the-year school-sponsored family outreach events. According to the principal:

We really were able to understand the West African presence in our community in ways that were staggering around two large events that we hosted last year. The first one was a Thanksgiving dinner. We hosted a Thanks giving dinner for the community and saw so many people come out... a lot of them in traditional African wear, they came out as families. We fed three hundred plus people for dinner on the night before Thanksgiving last year. And a lot of them this was their first experience of Thanksgiving in America ... [Another] event was a coat giveaway, working with a local non-profit organization. We ... collected 450 coats, and those coats disappeared in one hour. The vast majority of the coats were taken by new families that had arrived to this part of the city. And we understood that they were families because they asked for coat sizes that range from one-two-year-old kids all the way up to the kids that we have here. So through those events, [it] opened a window, open our eyes and open a window of opportunity for further partnerships with community outreach organizations that can support new immigrant families.

In her attempt to provide precollege programming to high school students, the external community partner's realization of the growing presence of African immigrant students was more subtle. According to the community partner: 
I don't know if it was ever a case that we saw a big influx of African immigrants at one particular time, so much as it was a gradual process over the years. It was a matter of creeping in a little bit at a time. As our programming became more focused and the college content became more focused, students and their families that wanted our programming sought us out to take advantage of our content.

Even still, the lack of a systematic process has meant that school officials have struggled in addressing the unique cultural challenges imposed by the changing community demographics. In addressing this issue, the director of student support stated:

It's work in progress [meeting the needs of immigrant students]. Progress primarily because I think ... we've just had an Aha moment. I know for me since I've been in this position this year, it's been like, oh my God, I didn't realize we had so many [West African students] and now they're coming in droves. And so now I kind of feel like my charge probably over the summer is to really think about what systems are we going to have in place. Because right now I feel like we're being very reactionary, right? Because we didn't know that this was going to happen or is happening, so we're just responding the best we can to it...we just need to make more concerted efforts... this is a real thing, you know, what do we have in place to serve our students.

While discussing a catalytic event that led to a paradigm shift for him, the school principal pointed to an interaction with the school's growing African immigrant Muslim population. He reflected on how an exchange with students regarding prayer led to an expansion in student programming:

A lot of our students happened to be Muslim Nigerians. And based on some of their requests, some of them had been leaving school to go to Jummah on Fridays. After consideration and [internal] discussion, we identified a Muslim [teacher] here at my school who is willing to lead an advisory that would satisfy the requirement for Jummah on a Friday. So on Fridays during our mentoring hour [school time where teachers are encouraged to mentor students and provide socio-emotional support] we now have an hour of power where young people have a place that they can go that is convenient where they can pray as they're expected to on Fridays.

Although additional work is needed, school officials point to the example displayed by the Muslim students, and others like it, where students 
petitioned for greater school-wide acknowledgment of students' cultural diversity, as the impetus for the creation of the school's monthly Multicultural Day. The director of student support services stated:

[F]or us as a guidance team...what I've tried to really promote and push [is] having [immigrant students] feel that sense of pride. Because...they want to assimilate and...disconnect from their background. And...any movement away from that is what they're looking for. [T]hrough our actions and our words [we] encourage students to be comfortable with differences ... I think that we as a school [have] made a tremendous effort in making [our immigrant population] feel like [this school is their] home and like they're valued and appreciated. For example, today is multicultural day [so] they went on a trip to go see Blank Panther, which in and of itself is an important cultural expression. We try to celebrate diversity in big and small ways, so for instance, we always have flags [of different countries around the world] up. [T] oday, I'm wearing my Haitian outfit ...for students and staff alike to...see a part of who we are...The more the demographics started to change...the more we wanted everybody to feel like they belong. $[\mathrm{H}]$ aving certain days like today where...everybody came in [in] their gear and really celebrated...our babies in that way..is what...helps make it for them.

The community precollege partner has viewed cultural exchange programming as an essential part of the ability of her organization to instill pride in native-born Black students and African immigrant students. In arranging teleconference communications between the students in her program and African students on the continent, the precollege program director discussed how the communications have helped to facilitate a cross-cultural exchange to help Black students gain a better understanding of their African heritage and see their African immigrant peers in an improved light:

We held teleconferences every year with our program participants. It was a way to bring out a sense of pride for kids who are African coming from different countries where they were a little shy and whatever. But it also helped the African American students to see Africa in a better light, which is so critical to their own personal development. We found that when the African American students gained a better understanding of Africa they gain a better appreciation of African immigrant students. 
The science teacher detailed how for both African and African American students in Newark, living in the United States can rob individuals of the ability to see themselves in important roles. In detailing his formal years growing up in Nigeria, and time spent as a young adult visiting extended family living in Europe, the teacher stated:

So, if you were to go to England it would not be strange to be serviced by a Nigerian doctor or a doctor of West African heritage right? But here in America, when you see an African American doctor, you sit up a little bit straighter because like, well here it's an anomaly. Despite the image of America as a place of chance and opportunity, it is at the same time so confining to our students. So, I admit I struggle with getting my native-born students to see their possibility than I do for my West African students, and I think that while there are many factors, not hav[ing] ever seen yourself in the roles that I'm trying to get you to envision for yourself is at least part of the issue.

The final two themes that emerged from the conversations with school personnel focused on the academic preparation of their West African student population and the need for additional research focused on the broad social needs of the burgeoning population. First, school personnel expressed general agreement that the West African students are the more academically engaged segment of the student population. The school principal remarked:

We have kids coming here, not saying maybe I'll go to college, they are saying I want college and only that. So, this is the kind of hunger that's fascinating and it's what we as educators have been wishing for all the along. Can I get a population that's just hungry for education? We see this population as a core part of the change in our academic offering. We know that programmatically, what we will offer [our] kids in the future is different because now we have a group of students who are, who are crying and demanding and begging for it [education].

Based on the overwhelming interest of the school's West African student population, the high school is looking to fully revamp its academic programming through several partnerships with Newark-based colleges and universities. The expanded programming will include additional dual college credit course offerings, from the current limit of 25 slots to accommodate upwards of 100 more students. According to the principal: 
Honestly, we did not have as great a need for math and engineering [college course] offerings before our West African immigrants arrived, and now that they're here and they're saying I want this, we feel the need to expand our academic programming. ... We have written a grant with that focus on college access and college success. We didn't specifically name our West African kids, but we wrote it literally, I'm telling you, with the thinking that came out of the need of what we saw from this hunger for more and more college kinds of offerings.

Moreover, in her review of transcripts of recently arrived West African students, the director of student support services opined that West African students enter the high school with more advanced academic achievement levels than their native-born counterparts. In her experiences, the student support administrator contended that the traditional US high school model of assessing credit accumulation by number of hours students receive seat-time instruction does not fully recognize the talents of recently arrived West African immigrant students. According to the school official:

[West African Students], they're coming from a position of strength and they don't even know it, you know, and I think that's kind of the thing that we don't talk about because they come with these amazing transcripts and you're fascinated because you're like, you need to be in college right now, right. And yet, you know, due to our system, you have to go through this high school process. And for me, I feel like it needs to be a whole revamping of how we look at education period because, and don't let me get started on my little soap box, but if we were to use this population as a platform to have that conversation, we would ask, "Are we really servicing our children for the next step?" because there's no reason why some of these babies have to go through some of these classes.

Rather than a seat-time model to measure academic proficiency, the student support administrator advocated for a competency-based system where academic reporting and advancement center around students' demonstration of knowledge and skills. The administrator added:

Understand, I'm not talking about a GED, I mean a regular high school diploma with all of the respect associated with the degree. The GED is looked upon negatively, unfortunately. Otherwise, I feel like it's a kind of a disservice that we're here trying to use transcripts to match what students' experience is and use it as a measure of perceived mastery within a content area. We do that as opposed to just maybe testing... you are tested as an 
eleventh grader let's put you in eleventh grade or you are a twelfth grader... let's put you in the twelfth grade... versus sitting here and measuring students' seat-time.

Next, the high school principal expounded on the critical moment presented by the burgeoning West African population in Newark and how there remains so much more the school and the larger community can do to address the social needs of African immigrants. The principal concluded in offering:

Now I have to think about systems that also are design[ed] to conduct meaningful outreach of our West African population. Who is the staff that I hire to make sure that when a family comes in, they see somebody or hear somebody that they can build this relationship, a trusting relationship with? This is a problem I understand is important for my school, but also for the city as a whole. We don't always understand this, but it is traumatizing when people don't see themselves in the social, educational, and social systems that they are asked to exist in.

\section{Conclusion}

Voluntary African immigration to the United States is a relatively new phenomenon, with much of the growth taking place during the later half of the twentieth century. Since the 1970s, the number of Africans migrating to the United States has nearly doubled in each subsequent decade. Today, Africans represent the fastest-growing group of immigrants in the United States, as well as the state of New Jersey. Much of the growth of the African immigrant population in New Jersey has been the result of individuals coming from West Africa. Currently the state of New Jersey has the fifth-largest population of native-born Africans in the country, with much of the growth fueled by demographic changes in the state's urban centers (Gambino et al., 2014). Leading the way in this population growth is the city of Newark. Anecdotal evidence suggests that new West African immigrants relocating to Newark are doing so though family unification provisions that enable family members of permanent residents and naturalized citizens expanded access to emigrate to the United States.

Moreover, US Census data shows that Newark's African immigrant population is concentrated in the city's North and East Wards. Within the city's wards, the largest percentage of immigrants with African ancestry 
reside in the Lower Clinton Hill neighborhood in the city's South Ward, followed closely by the Springfield neighborhood in the Central Ward, and 7\% in the Westside neighborhoods in the West Ward. Within Newark's West Ward, a local high school has attempted to address the unique needs of its expanding population of West African students. Exploratory interviews with school personnel suggest that West African youth are displaying a very high academic proficiency, leading school personnel to create a number of additional scholastic and social support services. Academically, school personnel anticipate expanding dual credit college offerings for the next school year. Furthermore, the school has implemented cultural diversity programming into their school calendar.

Attention to Newark's growing adolescent West African immigrant population provides the city with an excellent opportunity to learn from and provide more targeted support to an important subset of immigrant youth. Currently within the city of Newark there are a panoply of sophisticated youth-serving efforts underway that are designed to expand educational and employment avenues for the city's youth population. This programming includes, but is not limited to, the Newark City of Learning Collaborative, a collective impact initiative seeking to increase the postsecondary attainment of Newark residents from the current $18 \%$ to $25 \%$ by 2025 . On the other end of the spectrum is Newark's Opportunity Youth Network, an innovative partnership between the Newark Public School system, city officials, university partners, and a collection of high-functioning community-based organizations seeking to stem the tide of young people who leave school prior to graduating from high school. Moreover, there is the Newark 2020, a coalition made up of community stakeholders from the employment, academic, nonprofit, and governmental sectors seeking to increase employment opportunities for Newark residents. Just as these important efforts are providing such needed services to Newark residents, the Newark Public Schools will be returned to local control for the first time in nearly a quarter of a century. Local control means that local residents and governmental officials will have more authority in determining the educational programming and tracking educational progress of the city's more than 35,000 students. In each of the instances outlined above, increased awareness of and targeted services to Newark's burgeoning West African immigrant population offers an important avenue for greater positive youth outcomes. 
As such, based on the insight gleaned from this study, the authors recommend that future consideration in Newark should be given to:

- Development of a system to disaggregate student school level race/ ethnicity data to reflect students and their parents' immigrant status in order to understand the academic performance of immigrant students; and

- Development of a qualitative research initiative to explore the social interactions of West African immigrant youth, including challenges and opportunities regarding social acculturation and students' secondary academic achievement.

\section{REFERENCES}

Alexander, J. T., Leibbrand, C., Massey, C., \& Tolnay, S. (2017). Secondgeneration outcomes of the Great Migration. Demography, 54(6), 2249-2271. Anderson, M. (2015, April 9). A rising share of the U.S. Black population is foreign born. Washington, DC: Pew Research Center.

Anderson, M. J. (2017, February 14). African immigrant population in the U.S. steadily climbs. Washington, DC: Pew Research Center. Retrieved May 15, 2018, from http://www.pewresearch.org/fact-tank/2017/02/14/ african-immigrant-population-in-u-s-steadily-climbs

Anderson, M., Lopez, M. H., \& Rohal, M. (2015). A rising share of the U.S. Black population is foreign born; 9 percent are immigrants; and while most are from the Caribbean, Africans drive recent growth. Washington, DC: Pew Research Center.

Berlin, I. (1998). Many thousands gone: The first two centuries of slavery in North America. Cambridge, MA: The Belknap Press of Harvard University Press.

Capps, R., McCabe, K., and Fix, M. (2011). New streams: Black African migration to the United States. Washington, DC: Migration Policy Institute.

Edward, J. (2010). Bronx African American history project's (BAAHP) African immigrant research [White paper]. New York, NY: Fordham University.

Gambino, C., Trevelyan, E. N., \& Fitzwater, J. T. (2014). The foreign-born population from Africa: 2008-2012 (Report Number ACSBR/12-16). United States Census Bureau. Retrieved April 20, 2018, from https://www.census.gov/ library/publications/2014/acs/acsbrl2-16.html

Gordon, A. (1998). The new diaspora - African immigration to the United States. Journal of Third World Studies, XV(1), 79-103.

Grieco, E. M., \& Trevelyan, E. N. (2010). Place of birth of the foreign-born population: 2009 (ACSBR/09-15). Washington, DC: US Census Bureau.

Grieco, E. M., Trevelyan, E., Larsen, L., Acosta, Y. D., Gambino, C., de la Cruz, P., et al. (2012). The size, place of birth, and geographic distribution of the 
foreign-born population in the United States: 1960 to 2010 (Population Division Working Paper Number 96). Washington, DC: US Census Bureau.

Halter, M., \& Johnson, V. (2014). African \& American: West Africans in postcivil rights America. New York, NY: NYU Press.

Handlin, O. (1951). The uprooted: The epic story of the great migrations that made the American people. Boston, MA: Little Brown.

Lemann, N. (1991). The promised land: The great Black migration and how it changed America. New York, NY: Alfred A. Knopf.

Mathieu, S., (2009) The African American great migration reconsidered, OAH Magazine of History, 23(4), 19-23. Retrieved October 2009, from https:// doi.org/10.1093/maghis/23.4.19

Matthau, D. (2017). NJ used to have more immigration than today. Retrieved May 2, 2018, from https://nj1015.com/nj-used-to-have-more-immigrationthan-today/.

McCabe, K. (2011). African immigrants in the United States. Washington, DC: Migration Policy Institute. Retrieved May 9, 2018, from http://www.migrationinformation.org

Migration Policy Institute (MPI). (2017a). Children in U.S. immigrant families. Retrieved April 20, 2018, from https://www.migrationpolicy.org/programs/ data-hub/charts/children-immigrant-families

Migration Policy Institute (MPI). (2017b). U.S. immigrant population and share over time, 1850-present. Retrieved April 20, 2018, from https://www.migrationpolicy.org/programs/data-hub/charts/immigrant-population-over-time

Njue, J., \& Retish, P. (2010). Transitioning: Academic and social performance of African immigrant students in an American High School. Urban Education, 45(3), 347-370.

Segal, R. (1995). The Black diaspora: Five centuries of the Black experience outside Africa. New York, NY: Farrar, Straus and Giroux.

Shaw, D. V. (1994). Immigration and ethnicity in New Jersey History. Trenton, NJ: New Jersey Historical Commission, Dept. of State.

Statistical Atlas. (2018). Ancestry in Newark, New Jersey. Retrieved April 20, 2018, from https://statisticalatlas.com/place/New-Jersey/Newark/Ancestry

Thomas, K. (2011). A demographic profile of Black Caribbean immigrants in the United States. Washington, DC: Pennsylvania State University and Migration Policy Institute. Retrieved March 15, 2018, from https://www.migrationpolicy.org/research/CBI-demographic-profile-Black-caribbean-immigrants

Traoré, R., \& Lukens, R. (2006). This isn't the America I thought I'd find: African students in the urban U.S. high school. Lanham, MD: University Press of America.

U.S. Census Bureau. (2014). Sex by age by nativity and citizenship status (Black or African American alone). Universe: People who are Black or African American alone: 2010-2014 American community survey 5-year estimates. Retrieved April 20, 2018, from https://factfinder.census.gov/faces/tableservices/jsf/pages/ productview.xhtml?pid=ACS_14_5YR_B05003B\&prodType=table 
U.S. Congress, House of Representatives. (1965, August 25). Congressional record, 89th Congress, 1st Session. Washington, DC: U.S. Government Printing Office.

Ukpokodu, O. N. (2018). African immigrants, the 'new model minority': Examining the reality in U.S. k-12 schools. Urban Review, 50(1), 69-96.

Zainal, Z. (2007). Case study as a research method. Journal Kemanusiaan, $5(1), 1-6$.

Zong, J., \& Batalova, J. (2017, May 3). African immigrants in the United States. Migration Information Source. Retrieved May 2, 2018, from http://www. migrationpolicy.org/article/sub-saharan-african-immigrants-united-states

Zong, J., Batalova, J., \& Hallock, J. (2018, February 8). Frequently requested statistics on immigrants and immigration in the United States. Migration Information Source. Retrieved May 2, 2018, from https://www.migrationpolicy.org/article/frequently-requested-statistics-immigrants-and-immigrationunited-states

Open Access This chapter is licensed under the terms of the Creative Commons Attribution 4.0 International License (http://creativecommons.org/licenses/ by $/ 4.0 /$ ), which permits use, sharing, adaptation, distribution and reproduction in any medium or format, as long as you give appropriate credit to the original author(s) and the source, provide a link to the Creative Commons licence and indicate if changes were made.

The images or other third party material in this chapter are included in the chapter's Creative Commons licence, unless indicated otherwise in a credit line to the material. If material is not included in the chapter's Creative Commons licence and your intended use is not permitted by statutory regulation or exceeds the permitted use, you will need to obtain permission directly from the copyright holder.

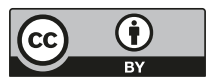

